\title{
Shift from non-pest to pest status in Rhopalomyia foliorum (Diptera: Cecidomyiidae), a species that induces leaf galls on Artemisia princeps (Asteraceae) cultivated as an edible plant in Okinawa, Japan
}

\author{
Tomoko Ganaha, ${ }^{1}$ Shinsuke Sato, ${ }^{2}$ Nami Uechi, ${ }^{3}$ Keith M. Harris, ${ }^{4}$ \\ Futoshi KAWAMURA ${ }^{5}$ and Junichi YUKawa, ${ }^{2,+\dagger}$ \\ ${ }^{1}$ Entomological Laboratory, Graduate School of Bioresource and Bioenvironmental Sciences, Kyushu University; Fukuoka \\ 812-8581, Japan \\ ${ }^{2}$ Entomological Laboratory, Faculty of Agriculture, Kyushu University; Fukuoka 812-8581, Japan \\ ${ }^{3}$ Okinawa Prefectural Agricultural Research Center; Okinawa 901-0336, Japan \\ ${ }^{4} 81$ Linden Way, Ripley, Woking, Surrey, GU23 6LP, UK \\ ${ }^{5}$ Okinawa Prefectural Plant Protection Center; Okinawa 902-0072, Japan
}

(Received 22 March 2007; Accepted 1 May 2007)

\begin{abstract}
In 2003, many small ellipsoidal or spindle-shaped leaf galls were found on Artemisia princeps (Asteraceae) that had been cultivated as an edible crop plant in Okinawa Prefecture, Japan. The galls were similar to those induced by Rhopalomyia foliorum (Diptera: Cecidomyiidae) on Artemisia vulgaris in Europe and those attributed to an unidentified Rhopalomyia species on wild A. montana and A. princeps in Japan. The morphological features and molecular sequencing data indicate that the pest gall midge in Okinawa and the unidentified species are identical to R. foliorum, which is redescribed, with new biological information. The proportion of cultivated Artemisia plants that bore the leaf galls was 55.63-96.46\%, a much higher proportion than on wild Artemisia. We consider that $R$. foliorum has shifted from non-pest to pest status in Artemisia fields under intensive cultivation that includes frequent harvesting of shoots and the application of rich nutrient fertilizer.
\end{abstract}

Key words: Gall midge pest; Rhopalomyia foliorum; Artemisia princeps; food crop; Okinawa

\section{INTRODUCTION}

Sometimes native non-pest herbivorous insects may suddenly become pests when some environmental factors have changed to favor the insects so that populations increase. In Japan, for example, land-use change and dry and hot summers have provided fruit bugs, such as Glaucias subpunctatus (Walker) and Plautia crossota stali Scott (Hemiptera: Pentatomidae), with good cone production of the conifers Cryptomeria japonica (Linnaeus) D. Don (Taxodiaceae) and Chamaecyparis obtusa (Siebold et Zuccarini) Endlicher (Cupressaceae). The good cone production has been responsible for their abundance during the last 30 years (e.g. Kiritani, 2006). Similarly, the maize or- ange leafhopper Cicadulina bipunctata (Melichar) (Hemiptera: Cicadellidae) has increased in number since 2001 possibly due to global warming with the extension of the maize-cultivating seasons resulting in outbreaks in 2004 (Matsumura et al., 2006). In North America, the Colorado potato beetle, Leptinotarsa decemlineata (Say) (Coleoptera: Chrysomelidae), rapidly became the most important and destructive insect pest of the cultivated potato after it had expanded its host range from an unknown ancestral host plant onto the potato some 150 years ago (Hare, 1990).

Artemisia princeps Pampanini (Asteraceae) is an herbaceous plant that occurs widely in Japan, except in Hokkaido and in the Korean Peninsula (Hotta et al., 1989). In Okinawa, the most southern

\footnotetext{
* To whom correspondence should be addressed at: E-mail: JZS02305@nifty.ne.jp

${ }^{\dagger}$ Present address: Matsuzaki 1-5-12, Fukuoka 813-0035, Japan

DOI: $10.1303 / \mathrm{aez} .2007 .487$
} 


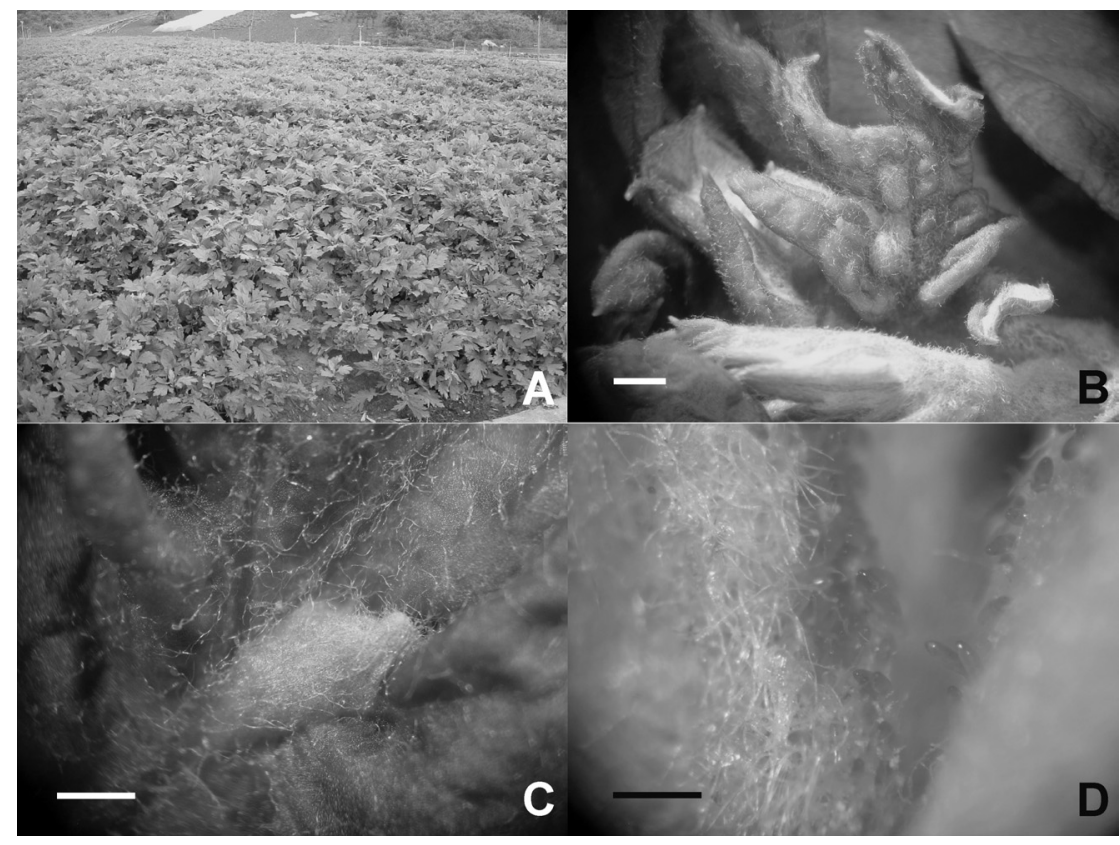

Fig. 1. Field of Artemisia princeps, and leaf galls and eggs of Rhopalomyia foliorum. A: Artemisia field in Ohton, Yaese Town, Okinawa Prefecture. B: Leaf galls induced on A. princeps by $R$. foliorum. Scale line: $2.0 \mathrm{~mm}$. C: Close-up of the leaf gall induced by $R$. foliorum. Scale line: $1.0 \mathrm{~mm}$. D: Eggs of $R$. foliorum laid on the surface of a young A. princeps leaf. Scale line: $0.3 \mathrm{~mm}$.

prefecture of Japan, A. princeps has been planted in private gardens and frequently used as an edible plant. Otherwise wild plants of $A$. princeps have been taken directly from the wild for occasional use. Young shoots of Artemisia are regularly used in Okinawa to flavor noodles, rice, and pork and vegetable dishes. The leaf galls render the cooking herb unsightly and unpalatable. About 30 years ago, a farmer started cultivating A. princeps commercially in Okinawa Prefecture (Fig. 1A). Thereafter, other farmers followed his lead and began to cultivate $A$. princeps extensively, using fertilizer. The area of Artemisia fields now covers at least 1.5 ha in Okinawa Prefecture. In May 2003, one of the farmers noticed and informed us of the presence of many small ellipsoidal or spindle-shaped galls (Fig. 1B and C) on upper- and undersurfaces of cultivated $A$. princeps leaves in his Artemisia field in Ohton, Yaese Town (previously Gushikami Village), Okinawa Prefecture. At once, we visited the same field to confirm the infestation of Artemisia leaves and initiated field surveys and collections. The gall inducer seemed to be a gall midge species of the genus Rhopalomyia (Diptera: Cecidomyiidae), which contains at least 250 species world-wide (Gagné, 2004). The galls were similar to those induced by Rhopalomyia foliorum (Loew, 1850) on the leaves of Artemisia vulgaris Linnaeus in Europe (Figs. 18-20 of plate 22 in Rübsaamen and Hedicke, 1926). The galls also resemble those induced by an unidentified species of Rhopalomyia (Rhopalomyia sp., hereafter) on Artemisia species in various places in Japan.

In order to identify the pest gall midge in Okinawa, we compared its morphological features and molecular sequencing data with those of $R$. foliorum collected from the UK and with the Rhopalomyia sp. from various localities in Japan. They induce similar leaf galls on Artemisia and therefore seemed to be appropriate candidates for comparison. Gall shape is generally species-specific (e.g. Yukawa and Rohfritsch, 2005), although a few species exhibit gall polymorphism (e.g. Ganaha et al., 2007; Mishima and Yukawa, 2007). In this paper, we identify the pest gall midge and provide information on its morphological features, host range, gall, distribution, and life history traits. We also report the present pest status of the gall midge and discuss reasons why this gall midge has become a pest in Okinawa Prefecture. 
Table 1. Comparison between cultivated and wild plants of Artemisia princeps in the proportion of plants that bore leaf galls induced by Rhopalomyia foliorum

\begin{tabular}{|c|c|c|c|c|c|c|c|}
\hline $\begin{array}{l}\text { Growing } \\
\text { conditions }\end{array}$ & Locality & $\begin{array}{l}\text { Latitude and } \\
\text { longitude }\end{array}$ & $\begin{array}{l}\text { Census } \\
\text { date }\end{array}$ & $\begin{array}{l}\text { Plant height } \\
\text { (cm) }\end{array}$ & $\begin{array}{c}\text { Plants } \\
\text { examined }\end{array}$ & $\begin{array}{l}\text { Plants bore } \\
\text { galls }\end{array}$ & $\%{ }^{a}$ \\
\hline Cultivation & $\begin{array}{l}\text { Ohton }\left(\text { Field } 1^{\mathrm{b}}\right) \text {, Yaese } \\
\text { Town, Okinawa Pref. }\end{array}$ & $\begin{array}{l}26^{\circ} 07^{\prime} 35^{\prime \prime} \mathrm{N} \\
127^{\circ} 44^{\prime} 6^{\prime \prime} \mathrm{E}\end{array}$ & 23 Jun. 2003 & - & 200 & 190 & $95.00 \mathrm{ab}$ \\
\hline Cultivation & $\begin{array}{l}\text { Ohton (Field 2), Yaese } \\
\text { Town, Okinawa Pref. }\end{array}$ & $\begin{array}{l}26^{\circ} 07^{\prime} 33^{\prime \prime} \mathrm{N} \\
127^{\circ} 43^{\prime} 57^{\prime \prime} \mathrm{E}\end{array}$ & 15 Feb. 2007 & $<30$ & 200 & 186 & $93.00 \mathrm{ab}$ \\
\hline Cultivation & $\begin{array}{l}\text { Ohton (Field 3), Yaese } \\
\text { Town, Okinawa Pref. }\end{array}$ & $\begin{array}{l}26^{\circ} 07^{\prime} 33^{\prime \prime} \mathrm{N} \\
127^{\circ} 44^{\prime} 06^{\prime \prime} \mathrm{E}\end{array}$ & 22 Feb. 2007 & $5-33$ & 339 & 327 & $96.46 \mathrm{a}$ \\
\hline Cultivation & $\begin{array}{l}\text { Ohton (Field 4), Yaese } \\
\text { Town, Okinawa Pref. }\end{array}$ & $\begin{array}{l}26^{\circ} 07^{\prime} 35^{\prime \prime} \mathrm{N} \\
127^{\circ} 43^{\prime} 59^{\prime \prime} \mathrm{E}\end{array}$ & 22 Feb. 2007 & $5-39$ & 302 & 168 & $55.63 \mathrm{~b}$ \\
\hline Grassland & $\begin{array}{l}\text { Yonashiro, Uruma City, } \\
\text { Okinawa Pref. }\end{array}$ & $\begin{array}{l}26^{\circ} 22^{\prime} 26^{\prime \prime} \mathrm{N} \\
127^{\circ} 58^{\prime} 44^{\prime \prime} \mathrm{E}\end{array}$ & 8 Mar. 2007 & $5-24$ & 48 & 1 & $2.08 \mathrm{c}$ \\
\hline Grassland & $\begin{array}{l}\text { Makabe, Itoman City, } \\
\text { Okinawa Pref. }\end{array}$ & $\begin{array}{l}26^{\circ} 06^{\prime} 25^{\prime \prime} \mathrm{N} \\
127^{\circ} 41^{\prime} 18^{\prime \prime} \mathrm{E}\end{array}$ & 9 Mar. 2007 & $2-42$ & 320 & 49 & $15.31 \mathrm{~d}$ \\
\hline River edge & $\begin{array}{l}\text { Matono, Kitagawa Town, } \\
\text { Miyazaki Pref. }\end{array}$ & $\begin{array}{l}32^{\circ} 39^{\prime} 14^{\prime \prime} \mathrm{N} \\
131^{\circ} 41^{\prime} 40^{\prime \prime} \mathrm{E}\end{array}$ & 27 Oct. 2006 & $50-90$ & 164 & 3 & $1.83 \mathrm{c}$ \\
\hline Riverbed & $\begin{array}{l}\text { Otomebashi, Mifune Town, } \\
\text { Kumamoto Pref. }\end{array}$ & $\begin{array}{l}32^{\circ} 41^{\prime} 34^{\prime \prime} \mathrm{N} \\
130^{\circ} 47^{\prime} 18^{\prime \prime} \mathrm{E}\end{array}$ & 5 Sep. 2006 & $50-90$ & 300 & 9 & $3.03 \mathrm{c}$ \\
\hline Riverbed & $\begin{array}{l}\text { Otomebashi, Mifune Town, } \\
\text { Kumamoto Pref. }\end{array}$ & $\begin{array}{l}32^{\circ} 41^{\prime} 34^{\prime \prime} \mathrm{N} \\
130^{\circ} 47^{\prime} 18^{\prime \prime} \mathrm{E}\end{array}$ & 2 Dec. 2006 & $\begin{array}{c}<15 \\
\text { (rosette type) }\end{array}$ & 250 & 4 & $1.60 \mathrm{c}$ \\
\hline
\end{tabular}

${ }^{\text {a }}$ Different small letters in this column indicate a significant difference (Turkey-Kramer's HSD test; $p=0.05$ ).

${ }^{\mathrm{b}}$ Field 1 includes two small patches of Artemisia.

\section{MATERIALS AND METHODS}

Gall midges of the genus Rhopalomyia. Almost all species of the genus Rhopalomyia induce galls on Asteraceae (Gagné, 1989, 1994). In Japan, 11 nominal and two unidentified species of the genus are known to induce galls on Artemisia, Dendranthema, and Chrysanthemum (Asteraceae) (Yukawa and Masuda, 1996; Nohara and Yukawa, 2003; Ganaha et al., 2004, 2007). Until now, only Rhopalomyia cinerarius Monzen and R. yomogicola (Matsumura) were known to occur in Okinawa Prefecture (Yamauchi et al., 1982; Yukawa and Masuda, 1996). In Japan, Rhopalomyia gall midges usually have two or more generations a year, overwinter as mature larvae in the galls on withered host plants and pupate in the galls (Yukawa and Masuda, 1996).

Collection and preservation of specimens, and morphological study. Leaf galls on $A$. princeps were collected in 2003 and 2007 by TG, NU, and FK from Ohton, Yaese Town, Okinawa Prefecture (Table 1), and in 2004 by TG and NU from Mt. Omoto-dake, Ishigaki Island, Okinawa Prefecture (Table 2). Whenever the opportunity arose during the period from 2002 to 2007, we collected small ellipsoidal or spindle-shaped galls induced by Rhopalomyia sp. on leaves of $A$. princeps from various localities in Japan, except Hokkaido. Those on A. montana were collected by TG and JY in 2004 from Hokkaido and Aomori Prefecture, northern Honshu (Table 2). In addition to our own collecting efforts, some of our colleagues cooperated in collecting the Rhopalomyia galls and gall midges at various localities in Japan (see details of specimens examined in the redescription of $R$. foliorum later in this paper). Larval, pupal, and adult specimens of $R$. foliorum were also collected from UK in 2002 and 2003 by KMH, NU, SS and JY (Table 2; and see also the specimens examined).

Eggs of the gall midge collected from Ohton, Yaese Town were measured under a binocular microscope. Some of the galls from Ohton were measured with slide-calipers to record gall size and then dissected under a binocular microscope to obtain gall midge larvae and pupae. In addition, we examined overwintering age structure of the pest gall midge by dissecting galls collected in February and March 2007 from Ohton, Yaese Town, Okinawa Prefecture. Unparasitized mature larvae and 


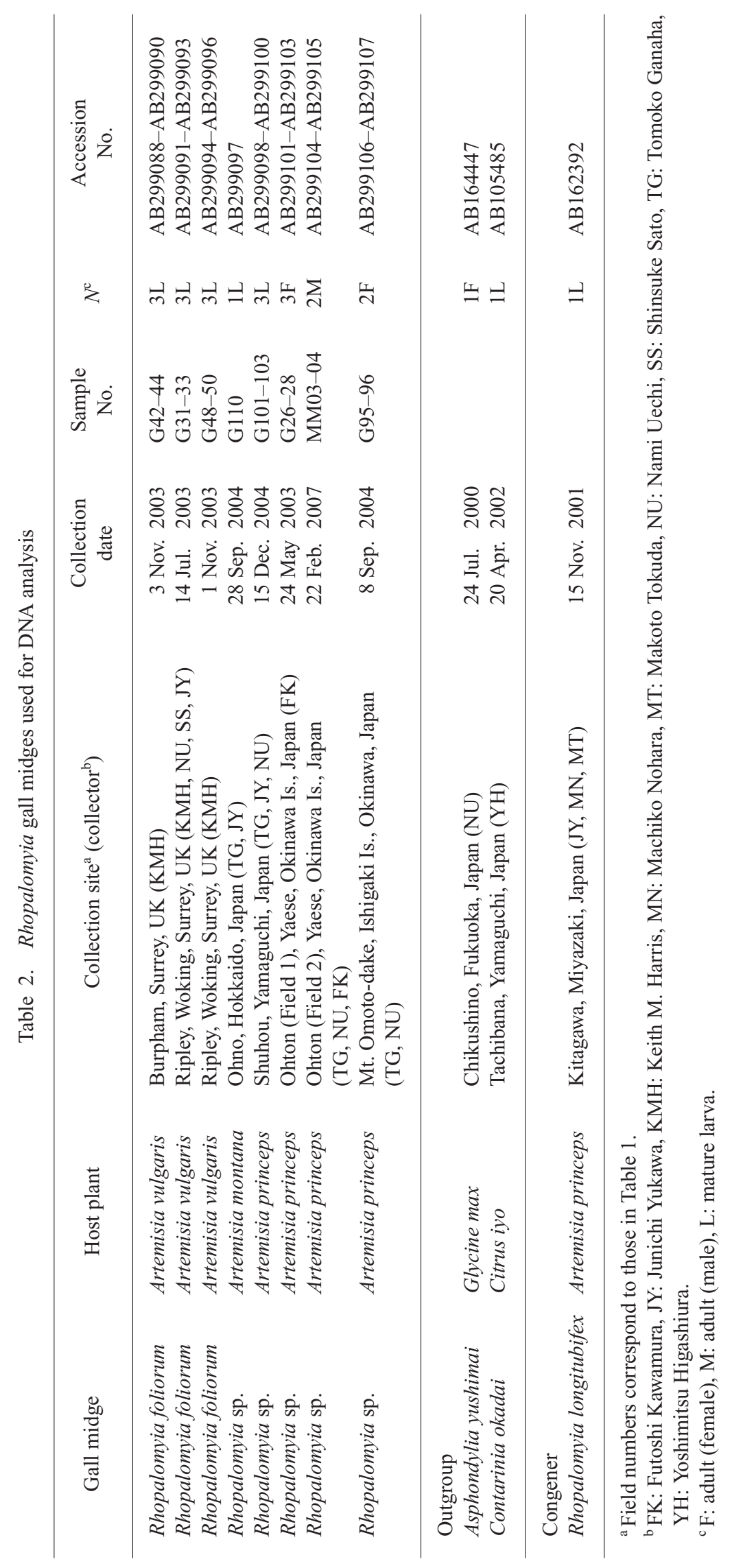


pupae were picked out of the galls and kept in $70-75 \%$ ethanol for morphological studies or in $99 \%$ acetone or ethanol for DNA analysis. The remaining galls were maintained in plastic containers (300 $\mathrm{mm}$ in diameter, $370 \mathrm{~mm}$ in depth) to rear adults. Adults emerging were also put into $70-75 \%$ ethanol or $99 \%$ acetone or ethanol.

The specimens stored in $70-75 \%$ ethanol were mounted on slides in Canada balsam for microscopic study, based on techniques outlined in Gagné (1989). These specimens were examined with bright-field and phase-contrast microscopy, using a Nikon ECLIPSE E400 microscope. Drawings were made with the aid of a drawing tube. Most of the adult morphological terminology follows usage in Gagné (1981). Morphological terminology of larvae generally follows usage in Möhn (1955; originally written in German) that was translated into English in Yukawa (1971), and the terminology of pupae follows that in Gagné (1994).

The slide-mounted specimens examined in this study are kept in the collection of the Entomological Laboratory, Faculty of Agriculture, Kyushu University, Fukuoka, Japan.

Field survey in Okinawa. In 2003 and 2007, the proportion of gall-bearing Artemisia plants was surveyed at several fields in Ohton, Yaese Town and grasslands in Itoman and Uruma Cities (Table 1). At the same time, we obtained from some farmers information on the history and methods of Artemisia cultivation, such as nursery management, time of shoot harvest, application of fertilizer, and use of insecticides. In addition, we searched for other Rhopalomyia gall midges on wild and cultivated Artemisia and cultivated Chrysanthemum in Ohton.

Field survey in Kyushu. To compare gall abundance in Artemisia fields with that in natural vegetation, the proportion of gall-bearing wild Artemisia plants was surveyed in 2006 in the dry riverbed of the Midorikawa River, Otomebashi, Mifune Town, Kumamoto Prefecture, Japan (Table $1)$. In this dry riverbed, $A$. princeps is one of the most dominant plant species and galls of Rhopalomyia are known to be most abundant in autumn (Ganaha et al., 2006). Wild plants of $A$. princeps were also surveyed in 2006 on the roadside near crop fields in Matono, the river edge of the Kitagawa River, Kitagawa Town, Miyazaki Prefecture, Japan. Gall abundance was expressed as the proportion of $A$. princeps plants that bore one or more galls. The average number of galls per leaf was not determined, because leaf size varied from tiny fresh leaves on extending shoots to fully developed leaves attached to main stems.

Molecular phylogenetic analysis. For every individual adult or larva analyzed, total DNA was extracted from the whole body with the Dneasy tissue kit (Qiagen, Japan) following the manufacturer's instructions. A region of the cytochrome oxidase subunit I (COI) gene fragment of mtDNA was amplified, purified, sequenced, and electrophoresed following the methods described by Yukawa et al. (2003). See Ganaha et al. (2007) for the primers used for the amplification. The sequence data reported in this study are deposited in the DNA Data Bank of Japan, the European Molecular Biology Laboratory, and the GenBank nucleotide sequence databases with the accession numbers shown in Table 2. The following outgroup taxa were included: Asphondylia yushimai Yukawa and Uechi that infests pods of Glycine max (Linnaeus) Merril (Fabaceae) (Accession No. AB164447) and Contarinia okadai (Miyoshi) collected from blossoms of Citrus iyo Hortorum ex Tanaka (Rutaceae) (Accession No. AB105485) (Table 2). A congeneric species Rhopalomyia longitubifex (Shinji) that induces axillary bud galls on Artemisia species (Accession No. AB162392) was also included in the analysis (Table 2).

The sequence data were analyzed with the neighbor-joining (NJ) method using the software package PHYLIP Version 3.66 (Felsenstein, 2006). Evolutionary distances were calculated by Kimura's two-parameter method (Kimura, 1980). The resulting trees were subjected to bootstrap analysis (Efron, 1982; Felsenstein, 1985) with 1,000 replications for the $\mathrm{NJ}$ cladogram.

\section{RESULTS}

\section{Information on the cultivation of $\boldsymbol{A}$. princeps in Okinawa}

The mean density of $A$. princeps plants cultivated in the fields was 60.6 to $130.3 / 0.25 \mathrm{~m}^{2}$, from which the mean density per $\mathrm{m}^{2}$ was estimated to be 242.4 to 521.0 (Table 3). Plant density was extremely high compared with the scattered distribution pattern of $A$. princeps under wild conditions. According to a farmer, young $A$. princeps plants 
Table 3. Density of Artemisia princeps plants cultivated in fields expressed as the mean number of plants per $0.5 \times 0.5 \mathrm{~m}$ quadrat

\begin{tabular}{crrr}
\hline Quadrat No. & Field 2 $^{\mathrm{a}}$ & Field 3 $^{\mathrm{a}}$ & Field 4 $^{\mathrm{a}}$ \\
\hline 1 & 122 & 73 & 49 \\
2 & 207 & 131 & 47 \\
3 & 105 & 165 & 104 \\
4 & 87 & 110 & 56 \\
5 & - & 100 & 47 \\
\hline Mean/0.25 m & 130.25 & 115.80 & 60.60 \\
\hline Calculated mean $/ 1 \mathrm{~m}^{2}$ & 521.00 & 463.20 & 242.4 \\
\hline
\end{tabular}

${ }^{\text {a }}$ Field numbers correspond to those in Table 1.

were originally transplanted from wild vegetation to the field and have been cultivated for at least 10 years with compound fertilizer 804 (Mitsubishi Chemical Agri, Inc., Japan) once a week and poultry manure occasionally. When the young plants grow up to about $30 \mathrm{~cm}$ in height, shoots of $A$. princeps are harvested periodically at about 45-day intervals. Old plants have been renewed by occasional transplantation of young plants.

\section{Morphological comparison and description}

Rhopalomyia species frequently exhibit speciesspecific features in the adult abdominal tergites and sternites and in larval and pupal morphology, such as dorsal and ventral papillae on the larval prothorax, larval terminal segment, and the pupal head. However, we could not find any morphological differences between the pest gall midge in Okinawa, R. foliorum in Europe, and Rhopalomyia sp. on $A$. princeps and A. montana in Japan (Fig. 2A-D; see also redescription below). Based on morphological comparison and results of molecular analysis (see below), the pest gall midge in Okinawa and Rhopalomyia sp. are identified as $R$. foliorum and redescribed below based on the Japanese and UK specimens, as the species was not fully described in the original description (Loew, 1850).

Rhopalomyia foliorum (Loew, 1850) (Fig. 2A-D) Cecidomyia foliorum Loew, 1850: 36.

Misospatha foliorum (Loew, 1850): Kieffer, 1913: 45.

Diarthronomyia foliorum (Loew, 1850): Rübsaamen and Hedicke, 1926; Barnes, 1949: 116; Möhn,
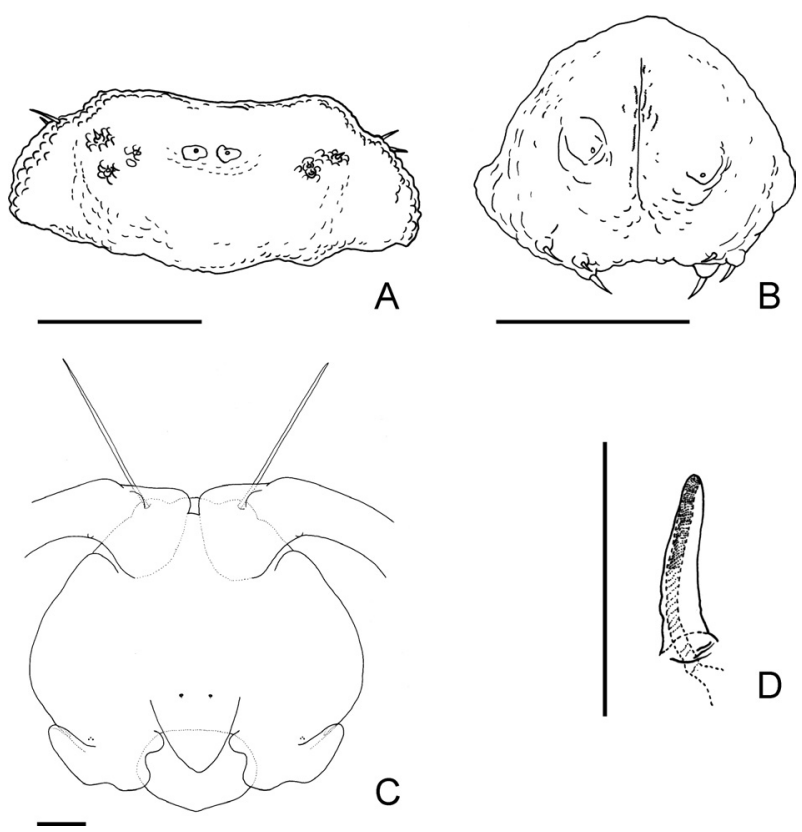

Fig. 2. Larva and pupa of Rhopalomyia foliorum. Scale lines: $0.1 \mathrm{~mm}$. A: Papillae on larval prothorax, ventral view. B: Larval terminal segment, ventral view. C: Pupal head. D: Pupal prothoracic spiracle.

1955: 162.

Rhopalomyia foliorum (Loew, 1850): Gagné, 1975: 483; Skuhravá, 1986: 193; Gagné, 2004: 242.

Hormomyia abrotani Trail, 1886: 250.

Japanese name. Yomogi-hime-eboshi tamabae.

Male. Eye bridge 4 facets long medially; frontoclypeal setae dense, 21 to 37 in number (Table 4). Palpus 2 segmented; length of first and second palpal segments varying between specimens. Antenna: scape with 5 to 10 setae; pedicel with a few setae; flagellomeres consisting of 13 to 14 segments; first and second flagellomeres fused; basal enlargement of third flagellomere 0.9 to 1.5 times as long as wide. Wing length $1.5-2.0 \mathrm{~mm}, 2.3$ to 2.6 times as long as wide (Table 4 ); $R_{5}$ joining costa at wing apex. Legs densely covered with blackish brown hairs; claws of all legs with basal tooth; empodium as long as claw; length of leg segments as in Table 4. Abdominal tergites I to VII rectangular, wider than long, with 2 to 3 caudal rows of setae and a pair of anterior trichoid sensilla; tergite VIII narrower than the preceding, with single caudal row of setae and a pair of anterior trichoid sensilla. Abdominal sternites II to IV rectangular, wider than long, with middle and caudal rows of setae, and a pair of anterior trichoid sensilla; sternites V to VII 
Table 4. Rhopalomyia foliorum: frontoclypeal and mesepimeral setal counts, and measurements of wing ( $\mathrm{mm})$, palpus $(\mu \mathrm{m})$, third flagellomere $(\mu \mathrm{m})$, and legs $(\mathrm{mm})$

\begin{tabular}{|c|c|c|c|c|c|c|c|}
\hline \multirow{2}{*}{\multicolumn{2}{|c|}{ Body parts }} & \multicolumn{3}{|c|}{$\hat{0}$} & \multicolumn{3}{|c|}{$q$} \\
\hline & & $n$ & mean $\pm \mathrm{SD}$ & (range) & $n$ & mean $\pm \mathrm{SD}$ & (range) \\
\hline \multirow{2}{*}{\multicolumn{2}{|c|}{$\begin{array}{l}\text { Frontoclypeal setae } \\
\text { Mesepimeral setae }\end{array}$}} & 9 & $28.2 \pm 5.1$ & $(21-37)$ & 10 & $27.8 \pm 5.6$ & $(21-39)$ \\
\hline & & 10 & $6.2 \pm 2.3$ & $(4-11)$ & 13 & $4.9 \pm 0.9$ & $(3-6)$ \\
\hline \multirow{3}{*}{\multicolumn{2}{|c|}{$\begin{array}{l}\text { Wing length } \\
\text { Wing width } \\
\text { Length/width }\end{array}$}} & 6 & $1.7 \pm 0.2$ & $(1.5-2.0)$ & 9 & $1.4 \pm 0.1$ & $(1.3-1.5)$ \\
\hline & & 6 & $0.7 \pm 0.1$ & $(0.6-0.8)$ & 9 & $0.5 \pm 0.0$ & $(0.5-0.6)$ \\
\hline & & 6 & $2.4 \pm 0.1$ & $(2.3-2.6)$ & 9 & $2.6 \pm 0.2$ & $(2.4-3.0)$ \\
\hline \multirow[t]{2}{*}{ Palpus } & 1 st segment & 7 & $25.7 \pm 8.6$ & $(12.5-37.5)$ & 7 & $22.9 \pm 6.5$ & $(17.5-35.0)$ \\
\hline & 2nd segment & 5 & $20.3 \pm 4.2$ & $(17.5-27.5)$ & 7 & $23.8 \pm 3.5$ & $(20.0-28.8)$ \\
\hline \multicolumn{8}{|c|}{ 3rd flagellomere } \\
\hline \multirow{3}{*}{\multicolumn{2}{|c|}{$\begin{array}{l}\text { Length of basal enlargement } \\
\text { Width of basal enlargement } \\
\text { Length of distal stem }\end{array}$}} & 9 & $51.7 \pm 4.3$ & $(45.0-57.5)$ & 12 & $57.4 \pm 4.7$ & $(47.5-62.5)$ \\
\hline & & 9 & $41.8 \pm 5.0$ & $(35.0-50.0)$ & 12 & $30.2 \pm 1.8$ & $(27.5-32.5)$ \\
\hline & & 9 & $38.9 \pm 5.6$ & $(32.5-45.0)$ & & - & - \\
\hline \multirow[t]{6}{*}{ Fore leg } & Femur & 9 & $0.7 \pm 0.1$ & $(0.5-0.8)$ & 11 & $0.5 \pm 0.1$ & $(0.4-0.6)$ \\
\hline & Tibia & 9 & $0.8 \pm 0.1$ & $(0.6-0.9)$ & 11 & $0.6 \pm 0.0$ & $(0.5-0.6)$ \\
\hline & Tarsomere 2 & 8 & $0.6 \pm 0.1$ & $(0.5-0.7)$ & 6 & $0.4 \pm 0.0$ & $(0.3-0.4)$ \\
\hline & Tarsomere 3 & 7 & 0.3 & $(0.3)$ & 6 & 0.2 & $(0.2)$ \\
\hline & Tarsomere 4 & 7 & 0.2 & $(0.2)$ & 6 & 0.1 & $(0.1)$ \\
\hline & Tarsomere 5 & 6 & 0.1 & $(0.1)$ & 6 & 0.1 & $(0.1)$ \\
\hline \multirow[t]{6}{*}{ Mid leg } & Femur & 9 & $0.7 \pm 0.1$ & $(0.6-0.8)$ & 11 & $0.5 \pm 0.1$ & $(0.4-0.6)$ \\
\hline & Tibia & 10 & $0.7 \pm 0.1$ & $(0.6-0.8)$ & 12 & $0.5 \pm 0.1$ & $(0.4-0.7)$ \\
\hline & Tarsomere 2 & 8 & $0.5 \pm 0.1$ & $(0.4-0.6)$ & 10 & $0.4 \pm 0.0$ & $(0.3-0.4)$ \\
\hline & Tarsomere 3 & 8 & $0.3 \pm 0.0$ & $(0.2-0.3)$ & 10 & 0.2 & $(0.2)$ \\
\hline & Tarsomere 4 & 8 & $0.2 \pm 0.0$ & $(0.1-0.2)$ & 9 & 0.1 & $(0.1)$ \\
\hline & Tarsomere 5 & 8 & 0.1 & $(0.1)$ & 9 & 0.1 & $(0.1)$ \\
\hline \multirow[t]{6}{*}{ Hind leg } & Femur & 10 & $0.8 \pm 0.1$ & $(0.6-0.9)$ & 13 & $0.7 \pm 0.1$ & $(0.5-0.8)$ \\
\hline & Tibia & 10 & $0.8 \pm 0.1$ & $(0.6-0.9)$ & 13 & $0.6 \pm 0.1$ & $(0.5-0.7)$ \\
\hline & Tarsomere 2 & 8 & $0.6 \pm 0.1$ & $(0.5-0.7)$ & 11 & $0.5 \pm 0.1$ & $(0.3-0.5)$ \\
\hline & Tarsomere 3 & 8 & $0.3 \pm 0.0$ & $(0.2-0.3)$ & 11 & $0.2 \pm 0.0$ & $(0.2-0.3)$ \\
\hline & Tarsomere 4 & 8 & $0.2 \pm 0.0$ & $(0.1-0.2)$ & 11 & 0.1 & $(0.1)$ \\
\hline & Tarsomere 5 & 8 & 0.1 & $(0.1)$ & 10 & 0.1 & $(0.1)$ \\
\hline
\end{tabular}

quadrate, the vestiture similarly arranged; sternite VIII with middle and caudal rows of setae, and without a pair of anterior trichoid sensilla. Genitalia: cerci setose, each large, rounded apically; hypoproct nearly as long as and distinctly narrower than cerci, the apex concave; gonostylus not distinctly arched, with a strong claw apically and fine hairs uniformly; inner angle of gonocoxite ventrally developed into a setose lobe, which is provided with a few protuberances; aedeagus longer than hypoproct, tapering to rounded apex. See Table 4 for detailed data of setal counts and meas- urements.

Female. Antenna with 11 to 12 flagellomeres; first and second flagellomeres fused; basal enlargement of third flagellomere 1.7 to 2.2 times as long as wide. Wing length 1.3 to $1.5 \mathrm{~mm}, 2.4$ to 3.0 times as long as wide (Table 4). Length of leg segments as in Table 4. Abdominal tergites I to VI rectangular, wider than long, with single caudal row of setae and a pair of anterior trichoid sensilla; tergite VII narrower than the preceding, the vestiture similarly arranged; tergite VIII distinctly narrower than tergite VII, bare, with only a pair of anterior 
trichoid sensilla. Abdominal sternites II to V rectangular, wider than long, with middle and caudal rows of setae, and a pair of anterior trichoid sensilla; sternites VI to VII as in male; sternite VIII not sclerotized, bare, without one pair of anterior trichoid sensilla. Ovipositor elongate, 437.5 to $525.0 \mu \mathrm{m}$ long, soft and pliable; cerci fused. Otherwise as in male. See Table 4 for detailed data of setal counts and measurements.

Egg. Usually many eggs are laid in a cluster within young shoots (Fig. 1D). Eggs are reddish orange and elongate ellipsoidal in shape with the mean long axis $0.27 \mathrm{~mm}(N=20$, ranging from 0.24 to $0.30 \mathrm{~mm}$ ) and the mean short axis $0.07 \mathrm{~mm}$ ( $N=20$, ranging from 0.06 to $0.08 \mathrm{~mm}$ ).

Mature larva. Body color milky white at first, changing to reddish orange at maturity; second antennal segment 10.0 to $16.3 \mu \mathrm{m}$ long; cervical papillae without seta; six dorsal papillae present on prothoracic segment; eight dorsal papillae present on meso- and metathorax and first through seventh abdominal segments, each with seta, 11.3 to $17.5 \mu \mathrm{m}$ long; two dorsal papillae of eighth abdominal segment each with 12.5 to $18.8 \mu \mathrm{m}$ long seta; two pleural papillae each with 8.8 to $16.3 \mu \mathrm{m}$ long seta; stigma present on prothorax and first through eighth abdominal segments; sternal spatula absent (Fig. 2A); lateral papillae reduced to two setose papillae on each side (Fig. 2A); two sternal papillae present on each thoracic segment without seta; inner pleural papillae on all thoracic segments with 8.8 to $16.3 \mu \mathrm{m}$ long seta; two anterior ventral papillae without seta; the pair of posterior ventral papillae each with 7.5 to $16.3 \mu \mathrm{m}$ long seta on first to seventh abdominal segments; two ventral papillae of eighth abdominal segment each with 7.5 to $15.0 \mu \mathrm{m}$ long seta; three pairs of terminal papillae each with seta 8.8 to $16.3 \mu \mathrm{m}$ long (Fig. 2B); two anal papillae without setae.

Pupa. Base of antenna gently rounded apically (Fig. 2C); cephalic pair of setae elongate, 145.0 to $188.8 \mu \mathrm{m}$ in length; frons smooth; one pair of lower facial papillae each with seta 3.8 to $7.5 \mu \mathrm{m}$ long (Fig. 2C); one of three pairs of lateral facial papillae each with seta 3.8 to $7.5 \mu \mathrm{m}$ long (Fig. $2 \mathrm{C}$ ); prothoracic spiracle 30.0 to $85.0 \mu \mathrm{m}$ in length, rounded apically (Fig. 2D); abdominal spiracles short, rounded apically, present on second to sixth abdominal segments.

Specimens examined. [From Ohton, Yaese
Town, Okinawa Prefecture, Japan] 5 males and 5 females (on slide, Cecid. Nos. C2301-C2310), galls collected by F. Kawamura on 24 May 2003, reared under laboratory conditions by T. Ganaha, emerged on 23 June 2003; 5 females and 6 pupae (on slide, Cecid. Nos. C2311-C2321), galls collected by T. Ganaha and N. Uechi on 23 June 2003, reared under laboratory conditions by T. Ganaha, emerged on 23 June 2003; 4 larvae and 3 pupae (on slide, Cecid. Nos. C2322-C2328), galls collected by T. Ganaha, F. Kawamura, and N. Uechi on 15 February 2007; 8 males and 6 females (on slide, Cecid. Nos. C2329-C2342), galls collected by T. Ganaha, F. Kawamura, and N. Uechi on 22 February 2007, reared under laboratory conditions by S. Sato, emerged on 2 March 2007.

[From Higashi Village, Okinawa Prefecture, Japan] 4 larvae (on slide, Cecid. Nos. C2343C2346), galls collected by H. Ikenaga on 11 December 1980.

[From UK] 5 males, 3 females and 4 larvae (on slide, Cecid. Nos. C2347-C2358), galls collected by K. M. Harris on 19 September 2002 from Burpham, Surrey; 9 pupae (on slide, Cecid. Nos. C2359-C2367), galls collected by K. M. Harris, S. Sato, N. Uechi, and J. Yukawa on 14 July 2003 from Ripley, Woking, Surrey.

In addition to these slide-mounted specimens, many other specimens collected from various localities in Japan are kept in $70-75 \%$ ethanol in the collection of Entomological Laboratory, Kyushu University, Japan.

Remarks. $R$. foliorum was compared with two Japanese congeners whose morphological features were fully redescribed recently (Ganaha et al., 2007; Nohara et al., 2007). Other Japanese congeners, as well as many other Palaearctic species, have been inadequately described for precise morphological comparison. $R$. foliorum is distinguishable from R. yomogicola (Matsumura) and R. longitubifex (Shinji) as follows: eye bridge 4 facets long and palpus 2 segmented in R. foliorum, while 5 to 6 facets long and 3 to 4 segmented in $R$. longitubifex; male abdominal tergite VII rectangular, as wide as the preceding in $R$. foliorum, while narrower than the preceding in $R$. yomogicola and $R$. longitubifex; male abdominal sternites II to VII with middle and caudal rows of setae in $R$. foliorum and $R$. yomogicola, while caudal rows of setae and scattered setae elsewhere in $R$. longitubifex; 
eight dorsal papillae present on larval meso- and metathorax and first through seventh abdominal segments in $R$. foliorum and $R$. yomogicola, while six dorsal papillae present in $R$. longitubifex; base of pupal antenna gently rounded apically in $R$. $f_{o-}$ liorum, while relatively long, well sclerotized, apically pointed in $R$. yomogicola.

\section{Biological information}

Host plants. Artemisia princeps Pampanini and A. montana (Nakai) Pampanini in Japan (Current data) and A. vulgaris Linnaeus in Europe (e.g. Barnes, 1949; Skuhravá, 1986). Artemisia indica Willdenow has been known to occur in southwestern parts of Japan including Okinawa Prefecture (Hotta et al., 1989), but we have not seen any galls of $R$. foliorum on $A$. indica. Farmers do not cultivate $A$. indica because of its bitter taste (personal communication with a farmer, 2007).

Both $A$. princeps and $A$. montana are included as different species in the section Artemisia by Satake et al. (1981). In other cases, the former is treated as a synonym of $A$. indica (Porcher et al., 2005) and the latter is included in A. vulgaris (Takematsu and Ichizen, 1987) or given a name A. vulgaris var. indica (Wallich) Maximowicz f. montana Nakai (Makino Herbarium Database of Plant Specimens, 2004). Inconsistency in these taxonomic treatments indicates that these Artemisia species are likely to be included in the same section and that $R$. foliorum induces galls on closely related species of

\section{Artemisia.}

Gall. Small ellipsoidal or spindle-shaped galls with fine whitish hairs on the surface are induced on the upper- or lower surface of Artemisia leaves. The distal part of the gall is sometimes twisted irregularly. Galls do not stand perpendicular to the leaves but are somewhat flattened against the leaf surface (Fig. 1B and C). The mean long axis of the galls is $2.54 \mathrm{~mm}(N=20$, ranging from 1.28 to $3.40 \mathrm{~mm}$ ) and the mean short axis is $1.10 \mathrm{~mm}$ ( $N=20$, ranging from 0.67 to $1.70 \mathrm{~mm}$ ). Each gall consists of a single larval chamber occupied by one gall midge larva or pupa.

Abundance of galls. In the Artemisia field in Ohton, Yaese Town, Okinawa Island, 95\% of 200 A. princeps plants surveyed bore the galls in 2003 (Table 1). In 2007, we confirmed that the heavy infestation has been continuing there, the proportion of gall-bearing plants ranging from 55.63 to $96.46 \%$ (Table 1). In contrast, the proportion of gall-bearing plants was significantly lower in the dry riverbed, river edge, and grassland than in Artemisia fields (Table 1).

Parasitoids in Japan. We reared for the first time several adults of a pteromalid species from the galls collected from Ohton in February 2007. The pteromalid was confirmed to be an endoparasitoid. Percentage parasitism by the wasp was only $2.11 \%$ in this case (Table 5) but about $90 \%$ in other cases.

Distribution. Japan (Hokkaido, Honshu, Shi-

Table 5. Age structure of $R$. foliorum overwintering in the galls collected in February to March 2007 from Ohton, Yaese Town, Okinawa Prefecture

\begin{tabular}{|c|c|c|c|}
\hline Content in the gall ${ }^{\mathrm{a}}$ & Note & Number & $\%$ \\
\hline 1st instar & The gall did not mature & 3 & 0.69 \\
\hline 2nd instar & The gall almost matured & 17 & 3.93 \\
\hline 3rd instar & The gall fully matured & 65 & 15.01 \\
\hline Pupa (early stage) & Eyes were not pigmented yet & 50 & 11.55 \\
\hline Pupa (late stage) & Eyes were pigmented & 103 & 23.79 \\
\hline Pupal exuviae & Adult has emerged & 107 & 24.71 \\
\hline Pteromalid Pupa & Midge larva seemed to be attacked & 7 & $1.62^{\mathrm{b}}$ \\
\hline Empty & Gall inhabitant has emerged long before & 81 & 18.71 \\
\hline Total galls dissected & & 433 & 100 \\
\hline
\end{tabular}

\footnotetext{
${ }^{a}$ Eggs were not counted because they were very tiny and did not exist in the galls, although many eggs were assumed to have been laid by adults emerged as indicated in this table.

${ }^{\mathrm{b}}$ Indicating apparent percentage parasitism by the pteromalid wasp. Actual parasitism, 7/332 (=65+50+103+107+7), would be $2.11 \%$ because the wasp is an endoparasitoid and lay eggs in young host larvae, and then mature parasitoid larvae come out of mature host larvae to pupate in the galls.
} 


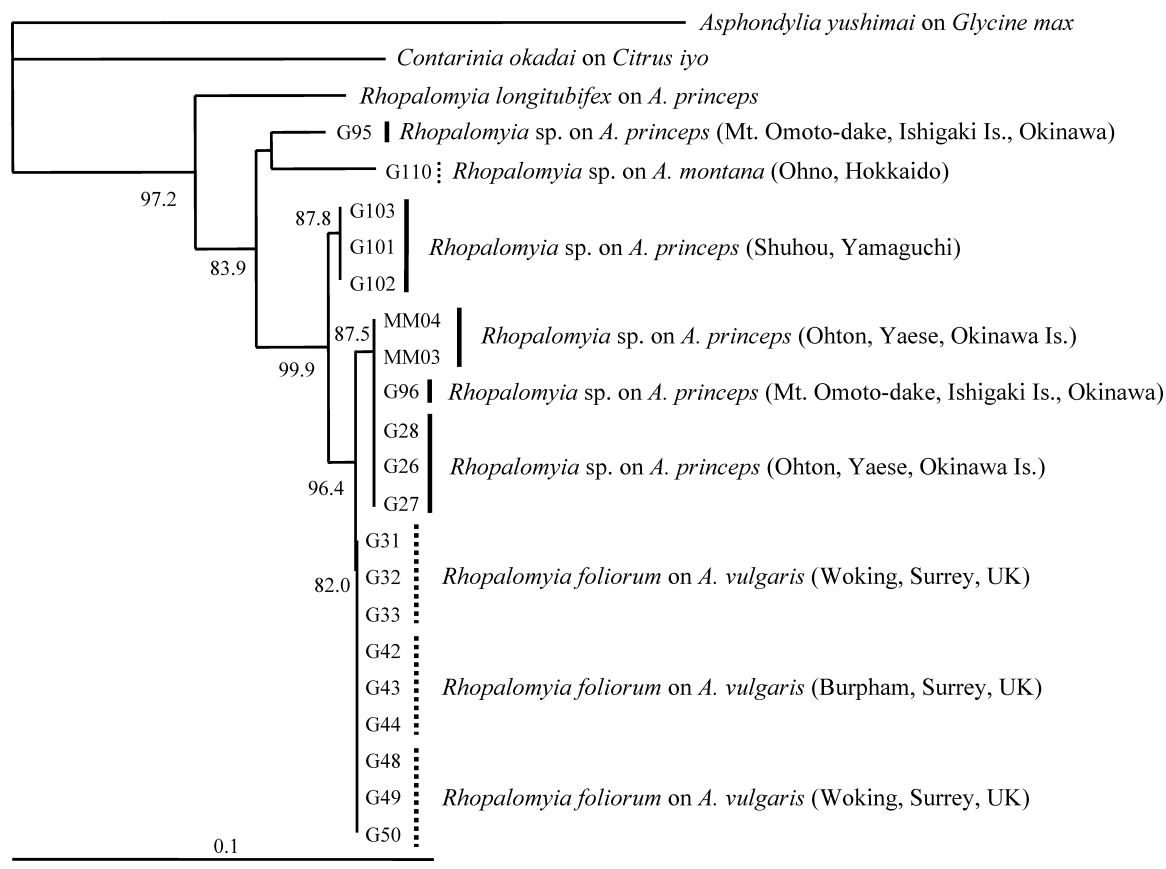

Fig. 3. NJ tree based on $439 \mathrm{bp}$ of the mtDNA COI gene for Rhopalomyia foliorum on Artemisia princeps in Japan and Artemisia vulgaris in the UK. Bootstrap values are indicated for nodes gaining more than $80 \%$ support (1,000 replications). Contarinia okadai and Asphondylia yushimai were used as outgroup species.

koku, Kyushu, and Okinawa and Ishigaki Islands) and Europe.

Life history. Current collecting data of specimens examined on slide mounts and those used for DNA analysis (Table 2), together with field data of gall abundance (Table 1) indicate that $R$. foliorum is multivoltine with overlapping generations in Japan. Recent records of this species in the UK indicate that it is multivoltine there and, although no detailed studies have been published, the same is probably true for the species in mainland Europe. The age structure of $R$. foliorum in February and March (Table 5) indicates that it overwinters, without entering diapause, at every developmental stage in Okinawa Prefecture and limited observations in the UK indicate that this is also the case there.

Other Rhopalomyia gall midges. Although $R$. cinerarius and $R$. yomogicola have been known to occur in Okinawa (Yamauchi et al., 1982; Yukawa and Masuda, 1996), we could not find them on wild and cultivated Artemisia and cultivated Chrysanthemum in Ohton.

\section{Molecular phylogenetic analysis}

The length of the amplified mitochondrial COI gene fragment was $439 \mathrm{bp}$. Monophyly of the clade including all $R$. foliorum individuals on $A$. vulgaris from UK, the pest gall midge on $A$. princeps from Okinawa, and Rhopalomyia sp. on A. princeps and A. montana from different localities in Japan was supported by a high bootstrap value (Fig. 3). The minimum genetic distance between the pest gall midge and $R$. foliorum from the UK was 0.0046 . The number of different nucleotides and deduced amino acid residues between them were $2(0.46 \%$ of $439 \mathrm{bp}$ ) and 0 , respectively. These data, together with morphological studies, indicate that the pest gall midge in Okinawa is identical with $R$. foliorum from the UK.

Some haplotypes were found in R. foliorum populations on different host plants and from different localities in Japan. The maximum genetic distance was 0.057 , which was recorded in two combinations: between individuals from Ohno, Hokkaido (No. G110) and Ohton, Yaese, Okinawa (No. G26-28, MM03-04) and between those from Ohno (No. G110) and Mt. Omoto-dake, Ishigaki Is., Okinawa (No. G96). The number of different nucleotides and deduced amino acid residues between them were $24(5.47 \%$ of $439 \mathrm{bp})$ and 2, respectively. 


\section{DISCUSSION}

Morphological features (Fig. 2A-D) and sequencing data (Fig. 3) indicate the pest gall midge in Okinawa and Rhopalomyia sp. on A. princeps and $A$. montana in Japan are identical with $R$. foliorum in Europe. The genetic distance was very short and the nucleotide difference was very small between $R$. foliorum populations in Okinawa and the UK, even though they are geographically so far apart at the eastern and western extremes of the Palaearctic Regions. In addition, several haplotypes exist in Japan. These facts indicate that $R$. $f_{0}$ liorum is not an alien gall midge in Japan but has been widely distributed in the Palaearctic Region and has recently expanded its habitat from wild to cultivated Artemisia in Japan.

The proportion of wild $A$. princeps plants that are galled by several Rhopalomyia species has been known to increase from spring through summer to autumn, but does not exceed $10 \%$ in the riverbed and $27 \%$ on the riverbank and around river edges (Ganaha et al., 2006). Therefore, a high proportion of gall-bearing plants in Artemisia fields (Table 1) indicates that $R$. foliorum has shifted from non-pest to pest status and reached an outbreak situation following the cultivation of $A$. princeps under high plant densities (Table 3).

As mentioned in the introduction, a shift from non-pest to pest status may be caused by drastic changes of land-use, cultivating methods, and control measures, effects of global warming, and introduction of new cultivars. In the case of $R$. foliorum in $A$. princeps fields, improvement of nutrient status by fertilizer application, combined with highdensity cultivation and occasional cutting of shoots and leaves might promote vigorous growth of new shoots. Under such conditions, $R$. foliorum would take advantage of continuous production of new shoots because it is a multivoltine species and does not enter winter diapause (Table 5) in a warm subtropical climate like Okinawa Prefecture.

Of course, occasional shoot harvesting would cause death of some gall midge larvae. Nevertheless, many galls might be induced and most gall midge larvae could survive, as has been well explained by the plant-vigor hypothesis (Price, 1991). Examples of population increase on vigorous plant parts have been demonstrated in various gall midge species, such as Dasineura marginemtorquens
(Bremi) on Salix viminalis Linnaeus (Salicaceae) (Glynn and Larsson, 1994), Contarinia sp. on Palicourea rigida Humboldt, Bonpland and Kunth (Rubiaceae) (Vieira et al., 1996), and Contarinia sp. on Bauhinia brevipes Vogel (Fabaceae) (Fernandes, 1998).

Until March 2007, no insecticides were registered on the list of agricultural chemicals that are allowed to be used against pests on Artemisia because the plant is not a major crop. In this study, we found a pteromalid species attacking the pest gall midge. Further investigation is needed to confirm if the extremely high population density of $R$. foliorum can be controlled with parasitoid species instead of insecticides, which may be ineffective against a pest that inhabits galls.

\section{ACKNOWLEDGEMENTS}

We thank anonymous referees for reviewing the manuscript of this paper for their critical reading of an early draft. We are grateful to Dr. M. Mishima (Kyushu University Museum) for her help in molecular analysis and to the following persons for their help in collecting and surveying the gall midge: Mr. $\mathrm{H}$. Ikenaga, Dr. M. Tokuda, Ms. K. Yonamine, Ms. C. Okamoto, Mr. Y. Tobita, and Mr. K. Matsuo. Our thanks are also due to Dr. K. Yasuda, Mr. T. Ooishi (Okinawa Prefectural Agricultural Research Center), Prof. O. Tadauchi, Dr. S. Kamitani, and Mr. D. Yamaguchi (Kyushu University) for their support in various ways. This study was partly supported by the Foundation for Riverfront Improvement and Restoration, Tokyo, Japan to JY. This study was also supported partly by the Research Fellowship of the Japanese Society for the Promotion of Sciences for Young Scientists to NU. This is a contribution from the Entomological Laboratory, Faculty of Agriculture, Kyushu University, Fukuoka (series 6, No. 32).

\section{REFERENCES}

Barnes, H. F. (1949) Gall Midges of Economic Importance. VI. Gall Midges of Miscellaneous Crops. Crosby Lockwood \& Son, London. 229 pp.

Efron, B. (1982) The Jackknife, the Bootstrap, and Other Resampling Plans. Society for Industrial and Applied Mathematics, Philadelphia. 92 pp.

Felsenstein, J. (1985) Confidence limits on phylogenies: an approach using the bootstrap. Evolution 39: 783-791.

Felsenstein, J. (2006) PHYLIP (Phylogeny Inference Package) Version 3.66. Department of Genomic Sciences, University of Washington, Seattle. Available from author at URL http:evolution.genetics.washington.edu/phylip. html [accessed on 8 February 2007].

Fernandes, G. W. (1998) Hypersensitivity as a phenotypic basis of plant induced resistance against a galling insect (Diptera: Cecidomyiidae). Environ. Entomol. 27: 260267.

Gagné, R. J. (1975) A redefinition of Diarthronomyia Felt as 
a subgenus of Rhopalomyia Rübsaamen (Diptera: Cecidomyiidae: Oligotrophidi). Ann. Entomol. Soc. Am. 68: 482-484.

Gagné, R. J. (1981) Cecidomyiidae. In Manual of Nearctic Diptera. Vol. 1 (J. F. McAlpine, B. V. Peterson, G. E. Shewell, H. J. Teskey, J. R. Vockeroth and D. M. Wood eds.). Research Branch, Agriculture Canada Monograph 27, Canadian Government Publishing Centre, Hull, pp. 257-292.

Gagné, R. J. (1989) The Plant-Feeding Gall Midges of North America. Cornell University Press, Ithaca, NY. 356 pp.

Gagné, R. J. (1994) The Gall Midges of the Neotropical Region. Cornell University Press, Ithaca, NY. 352 pp.

Gagné, R. J. (2004) A catalog of the Cecidomyiidae (Diptera) of the world. Mem. Entomol. Soc. Wash. 25: 1-408.

Ganaha, T., J. Yukawa, N. Uechi, M. Nohara and J. C. Paik (2004) Identifications of some species of the genus Rhopalomyia (Diptera: Cecidomyiidae) inducing galls on Artemisia (Asteraceae) in Korea. Esakia 44: 45-55.

Ganaha, T., N. Uechi, M. Nohara, J. Yukawa and Y. Shimatani (2006) Effects of floods on the survival of Rhopalomyia gall midges (Diptera: Cecidomyiidae) associated with Artemisia princeps (Asteraceae) growing in a dry riverbed in Japan. In Galling Arthropods and Their Associates: Ecology and Evolution (K. Ozaki, J. Yukawa, T. Ohgushi and P. W. Price eds.). Springer-Verlag, Tokyo, pp. 67-77.

Ganaha, T., M. Nohara, S. Sato, N. Uechi, K. Yamagishi, S. Yamauchi and J. Yukawa (2007) Polymorphism of axillary bud galls induced by Rhopalomyia longitubifex (Diptera: Cecidomyiidae) on Artemisia princeps and A. montana (Asteraceae) in Japan and Korea, with the designation of new synonyms. Entomol. Sci. 10: 157-169.

Glynn, C. and S. Larsson (1994) Gall initiation success and fecundity of Dasineura marginemtorquens on variable Salix viminalis host plants. Entomol. Exp. Appl. 73: 11-17.

Hare, J. D. (1990) Ecology and management of the Colorado potato beetle. Annu. Rev. Entomol. 35: 81-100.

Hotta, M., K. Ogata, A. Nitta, K. Hoshikawa, M. Yanagi and K. Yamasaki (1989) Useful Plant of the World. Heibonsha, Tokyo. 1,499 pp. (in Japanese).

Kieffer, J. J. (1913) Diptera. Fam. Cecidomyidae. In Genera Insectorum. Fasc. 152 (P. Wytsman ed.). V. Verteneuil \& L. Desmet, Bruxelles. 346 pp., 15 pls.

Kimura, M. (1980) A simple model for estimating evolutionary rates of base substitutions through comparative studies of nucleotide sequences. J. Mol. Evol. 16: 111-120.

Kiritani, K. (2006) Predicting impacts of global warming on population dynamics and distribution of arthropods in Japan. Popul. Ecol. 48: 5-12.

Loew, H. (1850) Dipterologische Beiträge. Viecter Theil. Die Gallmücken. Programm K. Friedrich-Wilhelms-Gymnasiums zu Posen.

Makino Herbarium Database of Plant Specimens (2004) Tokyo Metropolitan University, Tokyo. <http://www.makino. shizen.metro-u.ac.jp/database.htm>

Matsumura, M., M. Tokuda and N. Endo (2006) Recent out- breaks of the maize orange leafhopper Cicadulina bipunctata inducing gall like structure on maize in Japan. In Galling Arthropods and Their Associates: Ecology and Evolution (K. Ozaki, J. Yukawa, T. Ohgushi and P. W. Price eds.). Springer-Verlag, Tokyo, pp. 149-158.

Mishima, M. and J. Yukawa (2007) Dimorphism of leaf galls induced by Pseudasphondylia neolitseae (Diptera: Cecidomyiidae) on Neolitsea sericea (Lauraceae) and their distributional patterns in Kyushu, Japan. Bull. Kyushu Univ. Mus. 5: 57-64.

Möhn, E. (1955) Beiträge zur Systematik der Larven der Itonididae (=Cecidomyiidae, Diptera). 1. Teil: Porricondylinae und Itonidinae Mitteleuropas. Zoologica 105 (1 and 2): 1-247, $30 \mathrm{pls}$.

Nohara, M. and J. Yukawa (2003) Generic position of two unidentified Japanese gall midges (Diptera: Cecidomyiidae) on Artemisia species (Asteraceae). Esakia 43: 27-33.

Nohara, M., T. Ganaha, N. Uechi, S. Sato and J. Yukawa (2007) Host range expansion by Rhopalomyia yomogicola (Diptera: Cecidomyiidae) from Artemisia princeps to an alien species of Artemisia (Asteraceae) confirmed by morphological features and molecular sequencing data. Entomol. Sci. (in press).

Price, P. W. (1991) The plant vigor hypothesis and herbivore attack. Oikos 62: 244-251.

Porcher, M. H. and collaborators (2005) Sorting Vigna Names. Multilingual Multiscript Plant Name Database (M.M.P.N.D)—A Work in Progress 1995-2020. School of Agriculture and Food Systems, Faculty of Land and Food Resources, The University of Melbourne, Melbourne, Australia <http://www.plantnames.unimelb.edu. au/Sorting/Artemisia.html>

Rübsaamen, E. H. and H. Hedicke (1926) Die Cecidomyiden (Gallmücken) und ihre Cecidien. Zoologica 29: 1-350, pls.

Satake, Y., J. Ohwi, S. Kitamura, S. Watari and T. Tominari (1981) Wild Flowers of Japan Herbaceous Plants. Vol. III. Heibonsha, Tokyo. 259 pp. (in Japanese).

Skuhravá, M. (1986) Family Cecidomyiidae. In Catalogue of Palaearctic Diptera. Vol. 4. Sciaridae-Anisopodidae (A. Soos and L. Papp eds.). Elsevier Publishing, Amsterdam, pp. 72-297.

Takematsu, T. and N. Ichizen (1987) Weeds of the World. Vol. I. Zenkoku Nôson Kyôiku Kyôkai, Tokyo. 712 pp. (in Japanese).

Trail, J. W. H. (1886) A new gall midge (Hormomyia abrotani sp. n.). Scot. Natur. 8: 250.

Vieira, E. M., I. Andrade and P. W. Price (1996) Fire effects on a Palocourea rigida (Rubiaceae) gall midge - a test of the plant vigor hypothesis. Biotropica 28: 210-217.

Yamauchi, S., H. Ikenaga and J. Yukawa (1982) Midge galls collected from the south-west islands of Japan. Satsuma 31: 1-23 (in Japanese with English summary).

Yukawa, J. (1971) A revision of the Japanese gall midges (Diptera: Cecidomyiidae). Mem. Fac. Agric. Kagoshima Univ. 8: 1-203.

Yukawa, J. and H. Masuda (1996) Insect and Mite Galls of Japan in Colors. Zenkoku Nôson Kyôiku Kyôkai, 
Tokyo. 826 pp. (in Japanese with English explanation for color plates).

Yukawa, J. and O. Rohfritsch (2005) Biology and ecology of gall-inducing Cecidomyiidae (Diptera). In Biology, Ecology, and Evolution of Gall-Inducing Arthropods. Vol. 1 (A. Raman, C. W. Schaefer and T. M. Withers eds.).
Science Publications, Enfield, pp. 273-304.

Yukawa, J., N. Uechi, M. Horikiri and M. Tuda (2003) Description of the soybean pod gall midge, Asphondylia yushimai sp. n. (Diptera: Cecidomyiidae), a major pest of soybean and findings of host alternation. Bull. Entomol. Res. 93: 73-86. 